\title{
Japanese open infectious disease lab despite local and national protests
}

Tokyo. This week, after waiting 20 years, hundreds of scientists at Japan's National Institute of Health will begin moving from their dilapidated headquarters in Tokyo to a plush new building in another part of the city. The move has angered local residents, who fear that an accidental leak of contagious agents would harm a densely populated region that contains a hospital. And the construction itself has unearthed cultural artefacts as well as possible evidence of atrocities committed by Japan during the Second World War.

The institute, with more than 300 researchers, is the nation's leading centre for research into and control of infectious diseases. It is in a shabby, 60 -year-old building that once belonged to the now defunct Imperial Navy. The walls are cracking, the building looks as though it has never been given a fresh coat of paint and the dark corridors are grim even by the standards of Japan's notoriously drab national laboratories. Yet the institute plays a vital role in the control of infectious disease, much like the US Centers for Disease Control in Atlanta. The institute also screens the safety of vaccines, antibiotics and other biological products as well as carrying out basic research into infectious diseases.

The Ministry of Health and Welfare, which administers the institute, initially favoured a site in Tsukuba science city north of Tokyo. Although the plan was approved in the early 1970 s by the Diet, researchers fought hard against being sent to what was then just a collection of national laboratories in the middle of the paddy fields of Ibaraki Prefecture.

The Tsukuba plan was abandoned, and in 1986 the ministry announced a new plan to move to a site next to the National Medical Centre in Shinjuku Ward formerly occupied by a centre for handicapped children. But this idea has also encountered opposition.

The new site is in a densely populated area and local people are worried that a laboratory conducting experiments on the AIDS virus and other contagious agents could leak into the local environment. The laboratory will be at Level 3 on the internationally used biosafety scale of 1 to 4 , where 4 indicates a facility for handling large amounts of the most contagious agents.

According to Shudo Yamazaki, deputy director-general of the institute, the Level 3 laboratory will have double the necessary number of high-performance air filters capable of removing contagious agents as small as 0.3 micrometres. The new building has also been designed to stand up to an

earthquake comparable to the one in 1923 that flattened much of Tokyo.

Residents are demanding assurances that the building is completely safe, says Yamazaki, and opposition continues despite dozens of meetings with local residents. In 1989, residents filed suit in the Tokyo district court with the help of Shingo Shibata, a professor of social science at Hiroshima University. But the case is expected to languish for years in the grossly undermanned Japanese court system.

Local opposition is not the only problem facing the new facility. In 1987, shortly after construction began, pots and pans from the Yayoi Era (about 300 $B C$ to $A D$ 300) were unearthed and construction was halted for several months to allow excava-

The old (right)
and new
(below)
homes of the
Natlonal
Institute of
Health in
Tokyo.
Tokyo. are the remains of Chinese victims of biological experiments carried out in Manchuria during the Second World War - the site is the former location of the headquarters of a medical corps of the Japanese Imperial Army that performed the experiments.

The Ministry of Health and Welfare is
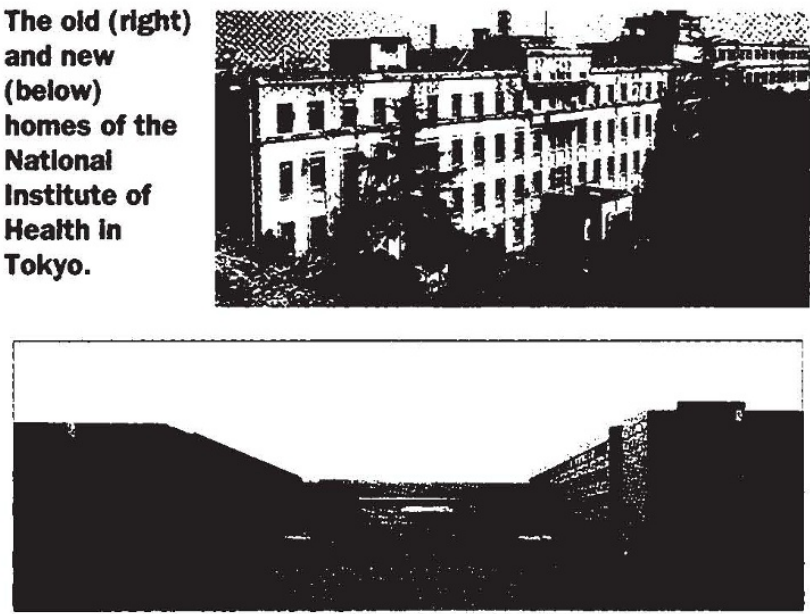

tion. When construction

resumed, riot police were used to quell a protest by a small group of students from nearby Waseda University, an action that still troubles residents and university officials.

As if that were not enough, in 1989 construction workers unearthed dozens of recently buried human bones of unknown origin. There is speculation that the bones studying the origin of the bones, but their nationality is difficult to determine, says Yamazaki. Although researchers would very much like to resolve both the controversy and their dispute with local residents before moving in, says Yamazaki, they believe that the dangerous condition of their present building requires them to move immediately.
David Swinbanks

\section{NEWS IN BRIEF}

Washington. Igor Shafarevich, a Russian mathematician who was last month asked to resign from the US National Academy of Sciences for alleged antisemitic writings and actions (see Nature 358,$442 ; 1992$ ), has told the academy that he will not do so. But a US mathematician who led the unprecedented campaign to oust Shafarevich remains hopeful that the academy's actions will induce Shafarevich's employer, the Steklov institute in Moscow, to improve its record of hiring and promoting Jewish researchers. In a letter dated 4 August, Shafarevich called the accusations of Frank Press, academy president, "absurd and scandalous", adding that "I do not know how you could have found positions in my work which do not exist". Although Press says that the academy cannot force Shafarevich to resign, Lawrence Shepp of AT\&T Bell Laboratories predicts that the Steklov Institute may quietly decide to adopt a policy of nondiscrimination during next month's election of a new director.
Washington. The US National Science Foundation has awarded grants to four universities in the second round of a programme that makes states, industry and the federal government equal partners in a cooperative research centre. Choosing from 24 applications, NSF agreed last week to give the University of Massachusetts at Amherst, the University of Oklahoma, the University of Rochester, New York, and the University of Texas at San Antonio roughly $\$ 1.2$ million over the next four years to support basic research related to various industrial applications. The programme is modelled on one begun more than a decade ago in which the federal government provides seed money for a centre that eventually derives its support solely from the private sector. NSF made six grants in the first year of the programme, developed in conjunction with the National Governors Association, but has no plans as yet for a third round because of an expected level budget in 1993 . 